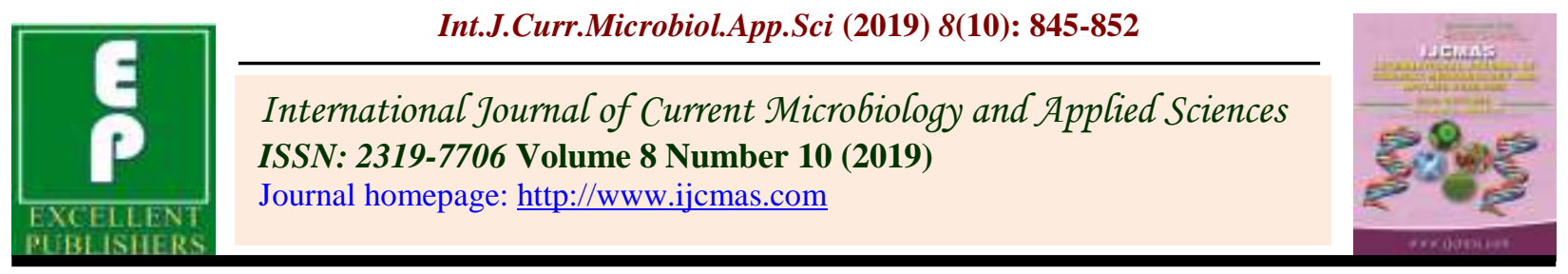

Original Research Article

https://doi.org/10.20546/ijcmas.2019.810.097

\title{
Development and Field Testing of a Sowing Attachment Suitable for Hilly Areas
}

\author{
Hijam Jiten Singh", H. Dayananda Singh and B. K. Sethy
}

ICAR Research Complex for NEH Region, Umiam-793103, Meghalaya, India

*Corresponding author

\begin{tabular}{|l|}
\hline Ke y w o r d s \\
Rice or maize \\
fallow, Light \\
weight, Sowing \\
attachment, Hilly \\
areas
\end{tabular}

A B S T R A C T
Mono-cropping practice is predominant under rain-fed agriculture in north east India, where rice is the most important crop followed by maize. It is apparent that areas under rice and maize remain fallow during the rabi season. These fallow lands can be effectively utilized for cultivation of rabi crops with improved technology. To achieve that sowing is a critical field operation that makes the prospects of a crop. However, farmers in the region still follow traditional methods. Therefore, a light weight power tiller $(4.1 \mathrm{~kW}$ petrol engine and $69 \mathrm{~kg}$ weight) operated sowing attachment was developed and its field testing was conducted. Rotor type seed metering mechanism was used in the sowing attachment. Seeds were placed in the furrows at a desire depth through adjustable system. The average depth of seed placement was $40 \mathrm{~mm}$. The maximum draft requirement was $294.3 \mathrm{~N}$ (Inverted-T type furrow opener) which was well within the capacity of the power source. Average field capacity, efficiency and man-hour requirement per hectare were $0.068 \mathrm{ha} / \mathrm{h}, 85 \%$ and 14.71 , respectively were for continuous operation at an average speed of $1.6 \mathrm{~km} / \mathrm{h}$. The savings in man-hours per hectare and cost of sowing were substantial as compared to conventional manual dibbling method.

\section{Introduction}

Rain-fed agriculture is predominant with mono-cropping practicein hilly areas of north east India, where rice is the major or important crop followed by maize. The region shares about $7.9 \%$ of the total geographical area, and about $3.8 \%$ of the total population of the country (Anon, 2011). The region is unique, affecting agriculture in various ways due to its location, climatic conditions and topography with wide variations in slopes and altitude. In the region, agricultural practices can be broadly of two distinct types, viz., (i) settled farming practices in the plains, valleys, foothills and terraces, and (ii) shifting cultivation practices on the hill slopes (Ngachan, 2011). Presently, the cropping intensity is as low as 136 per cent as compared to national average of 142 per cent during 
2014-15 (Anon, 2019). About $67 \%$ of area under rice remains fallow during the rabi season (Sabu et al., 2016). Apart from rice, maize farmers also leave their land fallow during the rabi season due to shortage of rainfall. These rice and maize fallows can be effectively utilized for cultivation of rabi pulses and oilseeds with an improved technological package. Institutions like ICAR or CAU or SAUs have been promoting minimum and no-till pulses and oilseeds cultivation in rice and maize fallows to achieve crop diversification and enhance cropping intensity thereby improving farmers' income and livelihood.

However, farmers in the region still follow traditional methods of manual sowing (broadcasting or dibbling). Manual methods of sowing using locally evolved hand tools are not only time consuming, but also labour intensive (200-250 man-hour per hectare) (Devnani, 1991), physically demanding and involve excessive drudgery.

Literature revealed that farm machines or equipment designed for plain areas are not suitable in the hilly region due to topography and small land holdings (Singh and Vatsa, 2007; Singh et al., 2014; Singh et al., 2017). Besides, farm equipment for the region must suit the terrain and small farm sizes. Some researchers reported seed drills and planters that can be used in hilly areas.

These include manually operated multi-crop planter for hilly areas (Gupta et al., 1999) and manually operated planter for maize (Khura $e t$ al., 2011). But, these manually operated improved equipments are physical demanding and give low output. There are also report of light weight power tiller operated seed drill for sowing wheat in hilly region (Singh and Vatsa, 2007); power tiller operated zero-till drill for mechanizing sowing of wheat in hills (Vatsa and Singh, 2014); and self-propel multi-crop planter for hill agriculture (Singh $e t$ al., 2014).Although some equipment has been developed for hilly areas, literature on study of light weight power tiller operated seed drills or planters suitable for the NEH region of India is scarcely available. Therefore, keeping the aforesaid observations in mind, attempt was made to develop and conduct field testing of a light weight power tiller operated sowing attachment for sowing bold seeded crops in hilly areas of north east India.

\section{Materials and Methods}

A two-row light weight power tiller operated sowing attachment was developed at Division of Agricultural Engineering, ICAR Research Complex for NEH Region, Umiam, Meghalaya. The target crops for the study were bold seeded crops such as maize, pea and soybean.

The major components were power source, main frame, hopper, metering unit, seed tube and furrow opener and ground wheels (Fig.1 and 2). Specifications of the developed sowing attachment are presented in Table 1. The details of materials used, methods and measurement techniques adopted during the course of investigation are discussed in this section.

\section{Machine components}

\section{Power source}

A4-stroke, $3600 \mathrm{rpm}, 4.1 \mathrm{~kW}$, recoil start petrol run engine (BCS Make light weight power tiller having $69 \mathrm{~kg}$ weight suitable in north east India) was used to operate the developed sowing attachment. Power transmission was achieved from the engine (through gearbox) to the drive wheels via drawbar power of the light weight power tiller and to the metering device through a transmission shaft from the drive wheel. 


\section{Main frame}

The main frame unit of $640 \times 330 \mathrm{~mm}$ was fabricated using square iron section of size $32 \times 32 \times 5 \mathrm{~mm}$. Seed hoppers with metering mechanism were mounted on the main frame. Two drive wheels, at the ends of a shaft (882 $\mathrm{mm}$ ), were fixed at the rear side using bushing arrangement below the main frame. Two furrow opener were attached to the frame with spacing of $250 \mathrm{~mm}$.

\section{Hopper}

The sowing attachment was provided with two hoppers with a volumetric capacity of 1677.34 $\mathrm{cm}^{3}$. The hoppers were made of $1 \mathrm{~mm}$ thick mild steel sheet. Seed hopper was made with consideration given to seed bulk density, volumetric capacity and angle of repose. The side wall slope of the hopper was provided with more than the angle of repose of the seed (30 degrees). The cross section of the hopper was rectangular in shape tapered towards the lower end (inverted frustum pyramid). Each hopper could hold $0.9 \mathrm{~kg}, 1.1 \mathrm{~kg}$ and $1.1 \mathrm{~kg}$ of pea, maize, and soybean respectively provided with a margin of $10 \mathrm{~mm}$ to prevent spillage of seed during operation in filed.

\section{Metering unit}

A rotor typed metering unit was modified from 6 cells for maize sowing and redesigned with 12 and 14 cells for sowing pea and soybean, respectively. The two rotor type seed metering units made of aluminium were mounted over a shaft connecting two drive wheels.

\section{Seed tube and furrow opener}

Seed tube and furrow opener were designed considering the required depth of seed placement. Seed tube was made of $25 \mathrm{~mm}$ diameter transparent plastic pipes with $2 \mathrm{~mm}$ wall thickness. The seed delivery spout height was close to the ground to reduce transverse seed dropping for uniform seed placement. Ttype furrow openers having $150 \mathrm{~mm}$ length, $33 \mathrm{~mm}$ width and $50 \mathrm{~mm}$ height were provided with seed outlets. The shank height of the furrow opener was $200 \mathrm{~mm}$. The furrow opener was bolted to the main frame with rigid clamps, and the depth of operation of the furrow opener was controlled by vertical adjustments of furrow opener clamp (0-50 $\mathrm{mm})$.

\section{Ground wheel}

Drive wheel of $400 \mathrm{~mm}$ diameter made up from $30 \mathrm{~mm}$ width and $5 \mathrm{~mm}$ thickness MS Flat and with 6 numbers of spoke and 12 numbers of pegs each of $40 \mathrm{~mm}$ radial outside projection from the periphery of the ground wheel. Each drive wheel has 6 numbers of spoke and 12 numbers of pegs each of $40 \mathrm{~mm}$ radial outside projection from the periphery of the drive wheel were fabricated.

\section{Laboratory calibration}

Laboratory calibration was conducted for three bold seeded crops (maize, pea and soybean) as shown in Figure 3 and 4. Maize seeds were filled in the two hoppers and ground wheels were jacked up. 20 revolutions were given to the ground wheels. Seeds discharged from each seed tube were collected and measured separately. Calibration was replicated ten times for better result. The same procedure was repeated for pea and soybean seeds. In the laboratory calibration, row-torow variation in seed metering were evaluated (IS: 6316-1993).

\section{Field testing}

Field testing of the developed prototype sowing attachment was conducted for sowing pea both at experimental farm of Division of 
Agricultural Engineering, ICAR Research Complex for NEH Region Umiam, Meghalaya and at farmers' field covered with stubble (rice fallow land). The sowing attachment was operated at a forward speed of $1.6 \mathrm{~km} / \mathrm{h}$. Rowto-row and average plant-to-plant spacing adopted on the field were $250 \times 112 \mathrm{~mm}$ for sowing field pea. Experiments were conducted in sandy loam soil covering a total area of 0.25 ha. Observations on time taken to cover the area, actual depth of placement, fuel consumption and speed of forward travel were recorded. Parameters such as soil bulk density, soil moisture content, soil resistance and draft requirement were also studied during the field testing. The performance of the sowing attachment was indicated by field capacity, field efficiency and draft requirement. The total cost of sowing was determined based on fixed cost and variable cost (IS: 1964-1979).

\section{Results and Discussion}

\section{Laboratory calibration}

In the laboratory, variation of seed discharged between two rows is shown in Table 2. The average quantity of seeds discharged in 20 revolutions of the ground wheel were $26.2 \mathrm{~g}$, $52.3 \mathrm{~g}$ and $79 \mathrm{~g}$ at the seed rate of $20.85 \mathrm{~kg} / \mathrm{h}$, $83.25 \mathrm{~kg} / \mathrm{h}$ and $62.87 \mathrm{~kg} / \mathrm{ha}$ for maize, pea and soybean seeds, respectively.

The maximum deviation of seed discharge at any row from the average was within the range of $7 \%$ as prescribed by the Bureau of Indian standards.

\section{Field testing}

The performance data of the developed sowing attachment at field is presented in Table 3. The average soil resistance per unit area (unit draft) of 138, 738 and $1170 \mathrm{kN} / \mathrm{m}^{2}$ was recorded at $50 \mathrm{~mm}, 100 \mathrm{~mm}$ and $200 \mathrm{~mm}$ depths, respectively using cone penetrometer. The sowing attachment had a maximum draft requirement of $0.29 \mathrm{kN}$ during field operation at soil moisture of 40.87 per cent(w.b) and bulk density of $0.9507 \mathrm{~g} / \mathrm{cm}^{3}$. The average field capacity was $0.068 \mathrm{ha} / \mathrm{h}$ for continuous operation at an average forward speed of 1.6 $\mathrm{km} / \mathrm{h}$. The average field efficiency was $85 \%$ for sowing pea. The man-hour requirement of the prototype sowing attachment was 14.71 per hectare (Fig. 5).

The average seed placement depth was 40 $\mathrm{mm}$. Performance indices indicated that the prototype light weight power tiller operated sowing attachment performed satisfactorily and found suitable under prevalent field conditions in hilly areas of north east India. The sowing attachment was laterally balanced due to equal weight distribution along its longitudinal axis, and was thus convenient to the operator.

The two furrow openers for sowing field pea were located at $125 \mathrm{~mm}$ apart from the longitudinal axis provided additional lateral ground support to the machine. The weight of the sowing attachment was only $19.1 \mathrm{~kg}$, and thus can be lifted easily by one or two persons from one place to another.

The cost of the developed sowing attachment was estimated to be Rs. 6,500/- with per hectare cost of operation atRs.2,736/-. This cost of operation is much lower than the cost of conventional manual dibbling method of sowing (Rs. 7500/- per ha) indicating saving up to $63.52 \%$ of operational cost as compared to manual dibbling method.

The results obtained from the laboratory calibration revealed that the deviation of seed discharge was within the permissible range of $7 \%$ prescribed by the Bureau of Indian standards. At forward speed of $1.6 \mathrm{~km} / \mathrm{h}$, effective field capacity of the prototype sowing attachment was $0.068 \mathrm{ha} / \mathrm{h}$ with a field efficiency 85 per cent. 
The average depth of seed placement was 40 $\mathrm{mm}$. Saving man-hour requirement and cost of sowing with this sowing attachment was substantial as compared to manual dibbling method. Therefore, two row light weight power tiller drawn sowing attachment was found to be suitable for sowing pea in hilly region.

Table.1 Specifications of developed sowing attachment

\begin{tabular}{|c|c|}
\hline Component & Specification \\
\hline Overall size ( length $\mathrm{x}$ width $\mathrm{x}$ height) & $900 \times 700 \times 500 \mathrm{~mm}$ \\
\hline Number of row & 2 \\
\hline Row Spacing (Adjustable) & $250-500 \mathrm{~mm}$ \\
\hline Plant spacing (Adjustable) & $100-200 \mathrm{~mm}$ \\
\hline Seed metering & Rotor type with cells $(6,12$ or 14 cells) \\
\hline Number of seed hopper & 2, each having capacity of $1677.34 \mathrm{~cm}^{3}$ \\
\hline Number of furrow & 2 \\
\hline Type of furrow opener & T- type \\
\hline Power transmission & $1.6 \mathrm{~km} / \mathrm{h}$ \\
\hline Forward speed & $4.1 \mathrm{~kW} \mathrm{BCS} \mathrm{Make}$ \\
\hline Power source & $69 \mathrm{~kg}$ \\
\hline (Light weight power tiller) & $19.1 \mathrm{~kg}$ \\
\hline Weight of power source & \\
\hline Weight of prototype sowing attachment &
\end{tabular}

Table.2 Laboratory calibration of sowing attachment

\begin{tabular}{|c|c|c|c|c|c|c|}
\hline & \multicolumn{6}{|c|}{ Seed collected in 20 revolutions of ground wheel (g) } \\
\hline & \multicolumn{2}{|c|}{ Maize } & \multicolumn{2}{|c|}{ Pea } & \multicolumn{2}{|c|}{ Soybean } \\
\hline & Row 1 & Row 2 & Row 1 & Row 2 & Row 1 & Row 2 \\
\hline Average & 26.1 & 26.4 & 51.9 & 52.7 & 78.6 & 79.4 \\
\hline $\begin{array}{l}\text { Maximum deviation } \\
\text { from average, } \%\end{array}$ & 2.5 & 3.6 & 2.5 & 1.4 & 2.2 & 1.6 \\
\hline SD & 0.50 & 0.95 & 1.02 & 0.37 & 1.43 & 0.78 \\
\hline C.V., \% & 1.90 & 3.63 & 1.95 & 0.71 & 1.81 & 0.99 \\
\hline
\end{tabular}

Note: $\mathrm{SD}=$ Standard deviation, $\mathrm{C} . \mathrm{V} .=$ Coefficient of variation

Table.3 Field testing data of the developed sowing attachment

\begin{tabular}{|c|c|c|}
\hline Sl. No. & Performance parameter & Values \\
\hline $\mathbf{1}$ & Area cover, ha & 0.25 \\
\hline $\mathbf{2}$ & Avg. depth of placement, $\mathrm{mm}$ & 40 \\
\hline $\mathbf{3}$ & Forward speed, $\mathrm{km} / \mathrm{h}$ & 1.6 \\
\hline $\mathbf{4}$ & Maximum draft, $\mathrm{kN}$ & 0.294 \\
\hline $\mathbf{5}$ & Fuel consumption, $\mathrm{l} / \mathrm{h}$ & 0.8 \\
\hline $\mathbf{6}$ & Field capacity, ha/h & 0.068 \\
\hline $\mathbf{7}$ & Theoretical field capacity, ha/h & 0.080 \\
\hline $\mathbf{8}$ & Field efficiency, $\%$ & 85 \\
\hline
\end{tabular}


Fig.1 CAD model of protortype sowing attachment

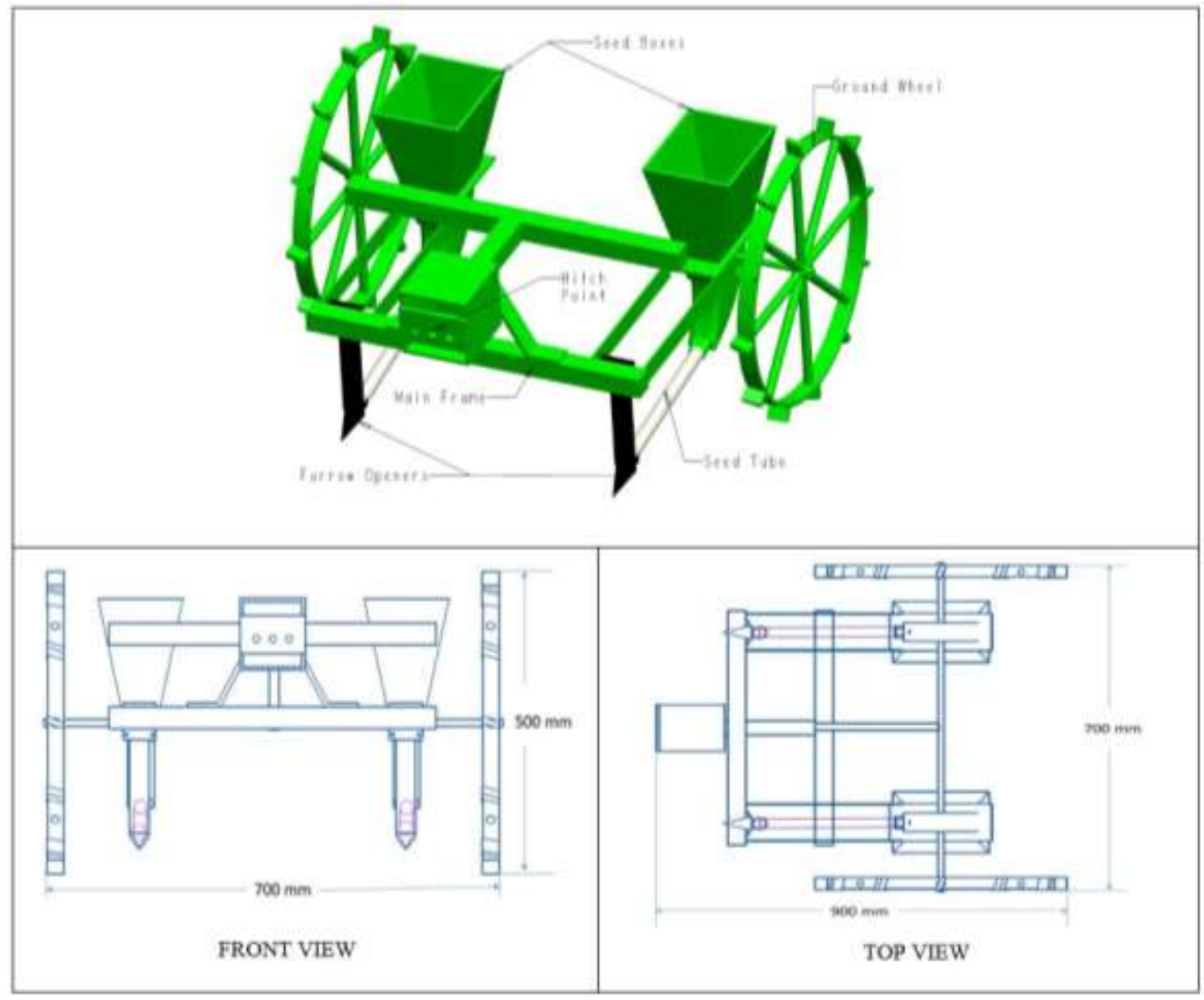

Fig.2 Fabricated prototype sowing attachment with seed metering unit
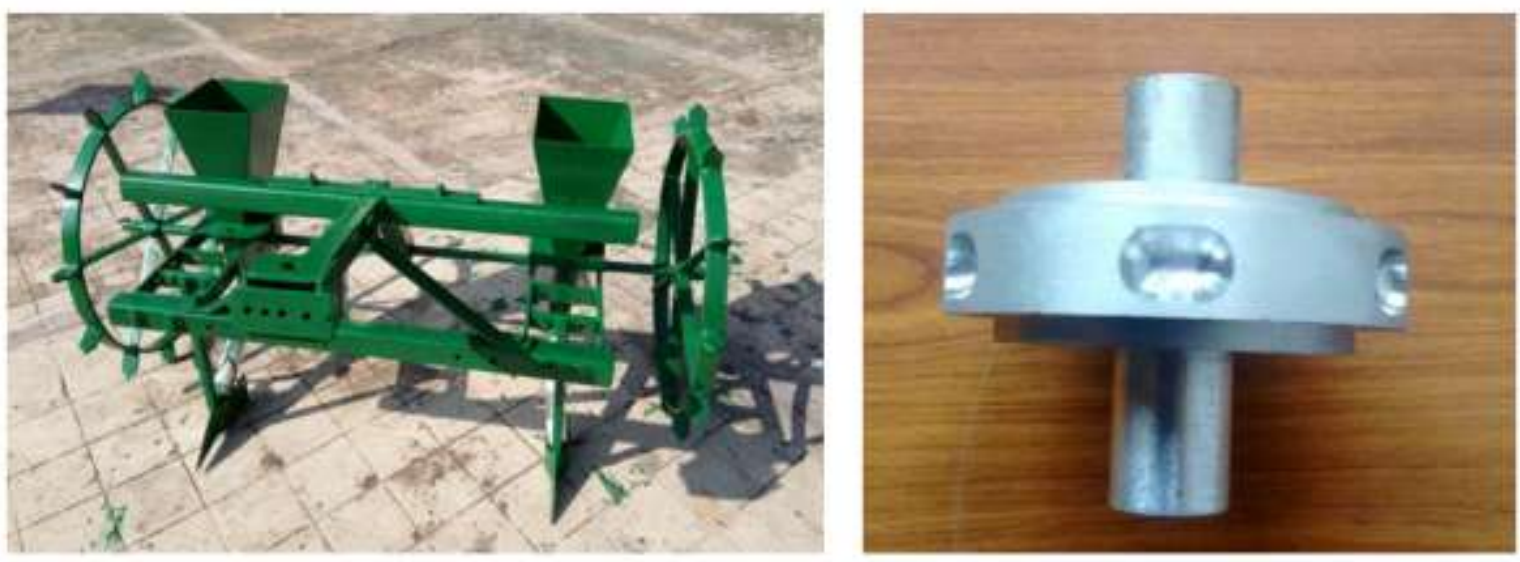
Fig.3 Calibration of developed sowing attachment

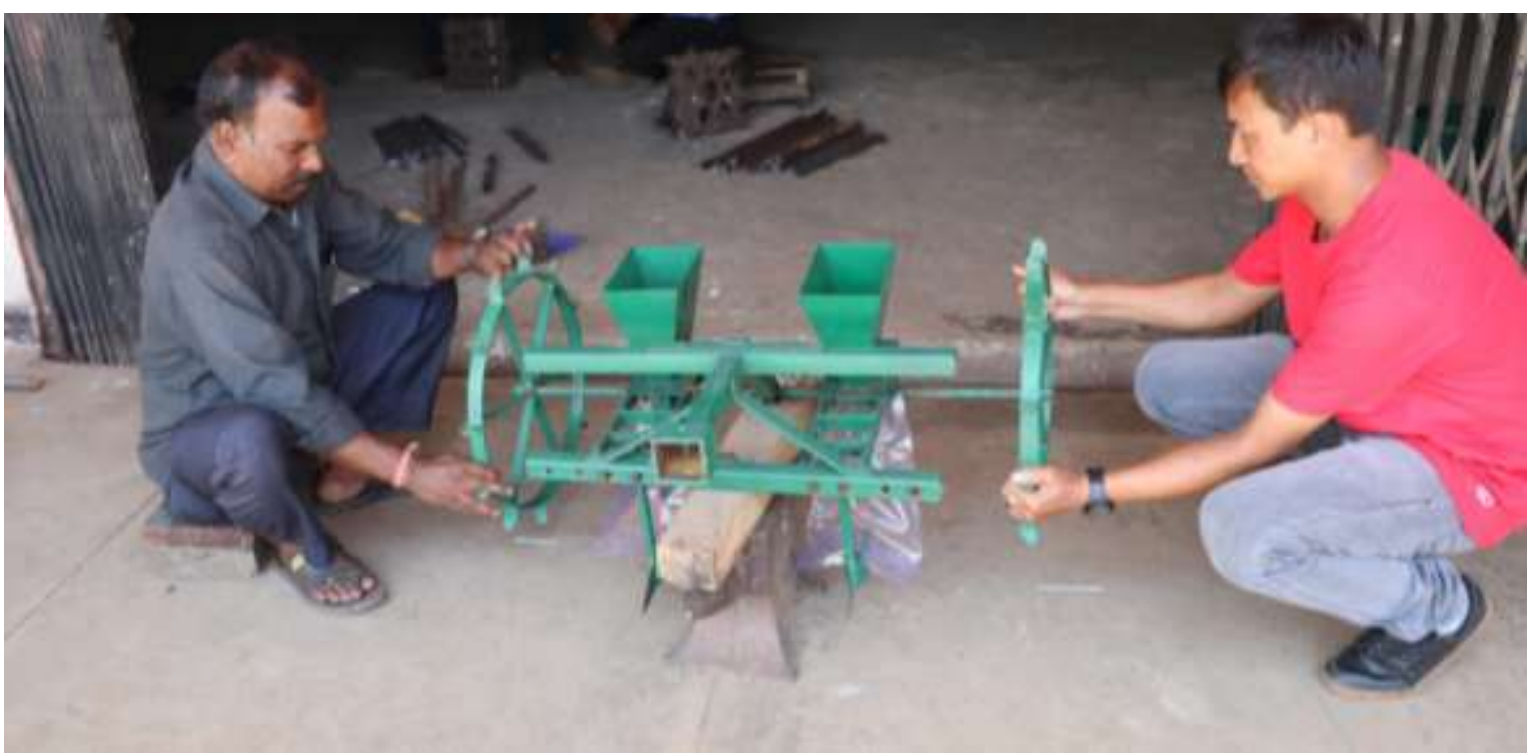

Fig.4 Seeds used in calibration of developed sowing attachment

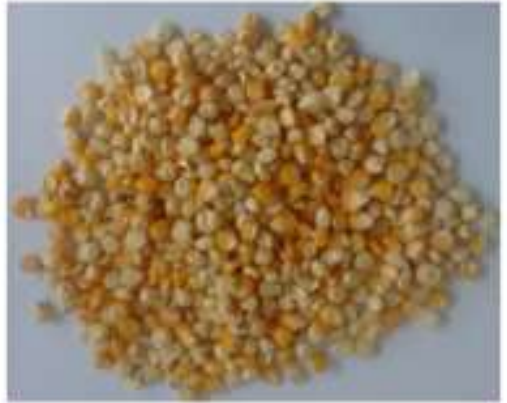

Maize

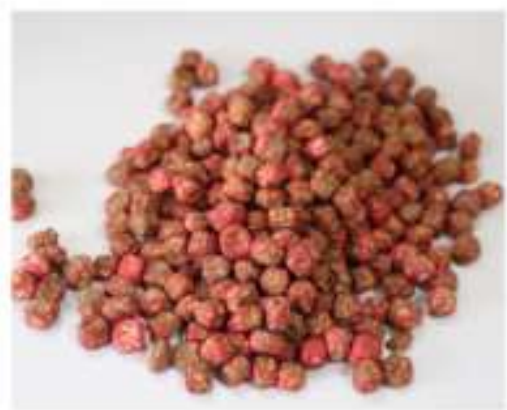

Pea

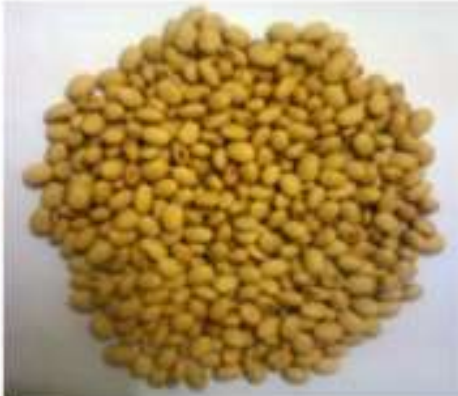

Soybean

Fig.5 Field testing of sowing attachment
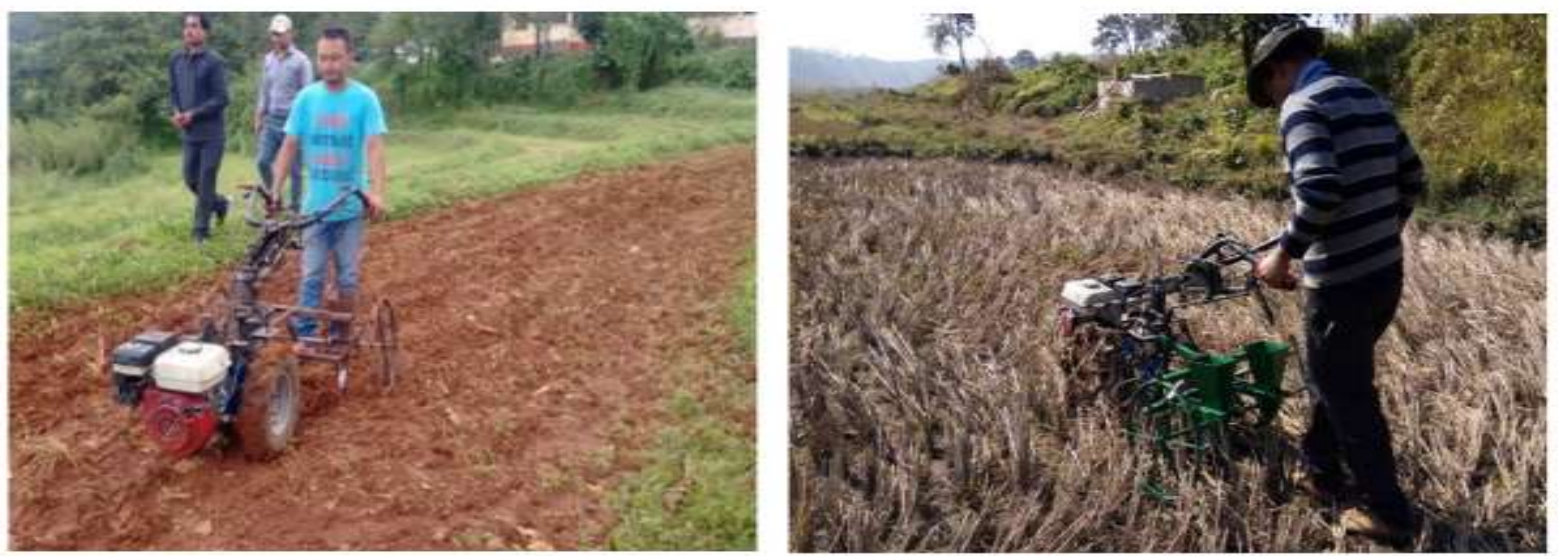


\section{Acknowledgement}

The authors would like to appreciate and thank the AICRP on Farm Implements and Machinery for providing financial support and ICAR-Research Complex for NEH Region, Umiam Meghalaya for all the necessary technical support and facilities.

\section{References}

Anonymous. 2011. Census of India, Govt. of India. $\quad \mathrm{http}: / /$ censusindia.gov.in. Accessed on 16/08/2019.

Anonymous. 2019.2 Indiastat. https://www.indiastat.com/table/agricu lture-data/2/agricultural-area-landuse/152/1084209/data.aspx. Accessed on $16 / 08 / 2019$.

Devnani, R.S.1991. Agricultural machinery design and data hand book seeders \& planters. Regional Network for Agric. Machinery of United Nations Development Programme, Bangkok, Thailand.

Gupta, M.L., Vatsa, D.K and Verma, M.K. 1999. Development and evaluation of multi-crop planter for hill regions. Agricultural Mechanization in Asia, Africa and Latin America, 30(1): 7-19.

Indian Standard.1993. Sowing equipment Seed-cum-fertilizer drill - Test code. IS:6316-1993. Bureau of Indian Standards, New Delhi.

Indian Standard. 1979. Guide for estimating cost of farm machinery operation. IS: 1964-1979. Bureau of Indian Standards, New Delhi.
Khura, T.K., Chauhan, N.S., Chandra, R. and Yadav, S.N. 2011. Mechanization of maize cultivation in Sikkim: Status and Strategy. In: Proceeding of national seminar on augmenting productivity of mountain farming through Agricultural Engineering interventions at CSK HPKV, Palampur.

Ngachan, S.V. 2011. Status and strategies for agricultural development in northeastern region. In: Compendium of North-Eastern Zone Regional AgriFair. pp. 1-4.

Singh, H.J., Dipankar, D., Sahoo, P. K. and Iquebal, M.A. 2014. Development and evaluation of self-propelled multicrop planter for hill agriculture. Journal of Agricultural Engineering, 51(2):1-8.

Singh, S., Sahoo, D.C. and Bisht, J.K. 2017. Development and performance evaluation of manual/bullock operated multicrop planter for hilly region. Agricultural Engineering International: CIGR Journal, 19(1): 81-86.

Singh, S. and Vatsa, D.K. 2007. Development and Evaluation of a light weight power tiller operated seed drill for hilly region. Agricultural Mechanization in Asia, Africa and Latin America, 38(2):45-47.

Vatsa, D. K. and Singh, S. 2014. Development and Evaluation of Power Tiller Operated Zero Till-Drill for Mechanizing Wheat Sowing in Hills. Agricultural Mechanization in Asia, Africa, and Latin America, 45(3): 86-89.

\section{How to cite this article:}

Hijam Jiten Singh, H. Dayananda Singh and Sethy, B. K. 2019. Development and Field Testing of a Sowing Attachment Suitable for Hilly Areas. Int.J.Curr.Microbiol.App.Sci. 8(10): 845852. doi: https://doi.org/10.20546/ijcmas.2019.810.097 